\title{
MUTATION RATE PADA ISOLAT Escherichia coli PENGHASIL EXTENDED SPECTRUM BETA LACTAMASE DARI PASIEN RAWAT INAP RSUD Dr. SOETOMO SURABAYA
}

\author{
Rendra bramanthi; ${ }^{\star 凶}$
}

\begin{abstract}
Abstrak
Pada awal 1980 enzim extended spectrum betalactamase (ESBL) mulai ditemukan pada beberapa galur E. coli, salah satu karena penggunaan antibiotik spektrum luas yang kurang tepat. Mutation rate adalah nilai rata-rata peluang mutasi pada tiap pembelahan sel yang berhubungan dengan peluang mutasi selama bakteri tersebut hidup. Adanya mutation rate pada E. coli menunjukan bahwa bakteri tersebut dapat beradaptasi dengan baik terhadap tekanan, dan hal ini menjadi masalah dalam terapi pada pasien dengan ISK. Pada penelitian ini dilakukan analisis nilai mutation rate dari E. coli penghasil ESBL sebagai penyebab infeksi saluran kemih (ISK) yang berasal dari sampel urin pasien rawat inap di RSUD Dr. Soetomo Surabaya, serta untuk mengetahui pola mutasinya. Bakteri E. coli penghasil ESBL dikultur pada dua puluh medium Muller Hinton $\operatorname{agar}(\mathrm{MHA})$ yang mengandung $100 \mu \mathrm{g}$ rifampisin. Nilai mutation rate didapat dari perbandingan koloni resisten terhadap rifampisin dibagi jumlah koloni yang tumbuh. Hasil penelitian menunjukkan bahwa $50 \%$ sampel adalah strong hypermutable dan sisanya sebanyak $50 \%$ adalah weakly hypermutable . Jadi, dapat disimpulkan bahwa bakteri $E$. coli penghasil ESBL telah bermutasi agar dapat beradaptasi pada tekanan seleksi selama proses evolusinya.
\end{abstract}

Kata kunci: Escherichia coli penghasil ESBL, mutation rate.

\section{MUTATION RATE OF EXTENDED SPECTRUM BETA LACTAMASE PRODUCING Escherichia coli ISOLATES FROM PATIENTS HOSPITALIZED IN Dr. SOETOMO PUBLIC HOSPITAL SURABAYA}

\begin{abstract}
In the early 1980s extended spectrum betalactamase enzymes began to be found in several strains of E. coli, due to the use of broad spectrum antibiotics that are less precise. Mutation rate is the average value that shows the type of mutation in a given time. The mutation rate in $E$. coli showed that these bacteria can adapt very well under stress condition, but in In this study we analyzed the mutation rate of ESBL-producing E. coli which comes from urine samples of hospitalized at Dr. Soetomo hospital Surabaya. The purpose of this study is to determine the mutation pattern and the frequency of mutations of ESBL-producing $E$. coli as a cause of urinary tract infection in hospitalized patients in Dr. Soetomo hospital Surabaya. In this study ESBLproducing $E$. coli was cultured on twenty Muller Hinton mediums which contain $100 \mu \mathrm{g}$ rifampicin. The mutation rate is obtained from the comparison of rifampicin-resistant colonies divided by the number that grows. This study found there were $50 \%$ strong hypermutable and the rest of $50 \%$ were weakly hypermutable ESBLproducing $E$. coli. It shows that these ESBL-producing $E$. coli have mutated to adapt in selection pressure during their evolutionary process.
\end{abstract}

Keywords: ESBL producing Escherichia coli, mutation rate.

*Departemen Mikrobiologi Klinik, Fakultas Kedokteran Universitas Brawijaya

E-mail: rendra.bramanthi@gmail.com 


\section{Pendahuluan}

Bakteri Escherichia coli (E. coli) penghasil extended spectrum beta $(\beta)$ lactamase (ESBL) telah banyak diketahui sebagai ancaman baru salah satu penyebab 45\% infeksi saluran kemih (ISK) Berdasarkan data Rumah Sakit Dr. Soetomo Surabaya periode Juli-September 2012 diketahui bahwa 51 isolat urin adalah penghasil ESBL Hal ini diduga karena pengunaan antibiotik yang berlebihan ${ }^{1-3}$ Kebanyakan isolat $E$. coli rumah sakit, terutama penyebab infeksi nosokomial, telah mengalami resisten pada beberapa antibiotik atau bahkan multiresisten. Kondisi resistensi pada patogen infeksius ini tidak hanya dijumpai di rumah sakit, namun juga pada pasien rawat jalan yang disebabkan oleh enterobacteriaceae penghasil ESBL. ESBL adalah $\beta$-lactamase dengan aktivitas spektrum luas yang terbentuk dari nonESBL $\beta$-lactamse yang mengalami mutasi. ESBL adalah tipe lain dari $\beta$-lactamase, seperti TEM (Temoneira), SHV (sulfydryl variable), CTX-M (cefotaxime hydrolyzing capabilities) dengan homologi sekitar 25\%. ${ }^{4}$ Golongan enzim ini kebanyakan dikode oleh plasmid sehingga mudah untuk ditransmisikan. ESBL menghidrolisis antibiotik betalactam yang menyebabkannya resisten terhadap penicillin, cephalosporin dan aztreonam. ${ }^{5}$

$\beta$-lactamase, terutama yang dihasilkan oleh golongan bakteri Gram negatif, adalah contoh evolusi mekanisme resistensi pada bakteri. Berdasarkan sekuen protein diketahui bahwa bakteri penghasil $\beta$ lactamase terbagi menjadi beberapa tipe yaitu $A, B, C$, dan $D$, serta tipe yang berkaitan dengan penicillin-binding protein. ${ }^{6-8}$

Agen antibakteri atau antibiotik diketahui dapat mempengaruhi mikroflora, yang tergantung pada dosis obat, rute pemberian, dan sifat farmakokinetik/dinamik agen tersebut. ${ }^{9}$ Namun, penggunaan antibiotik dalam jangka panjang telah menyebabkan resistensi pada beberapa bakteri. ${ }^{10}$

Munculnya resistensi pada bakteri adalah proses yang alami yang memungkinkan bakteri berrmutasi agar bisa menjadi resisten dan mampu hidup selama penggunaan antibiotik. Keadaan ini disebut juga tekanan seleksi yaitu bakteri yang sensitif akan mati, sedangkan bakteri yang bermutasi akan mampu hidup dan membelah diri. Proses mutasi yang terjadi biasanya diikuti oleh perubahan struktur biologi bakteri. ${ }^{11,12}$

Mutation rate adalah estimasi peluang mutasi pada tiap pembelahan sel yang berhubungan dengan peluang mutasi selama bakteri tersebut hidup. ${ }^{13}$ Beberapa bakteri mutator, yaitu bakteri yang memiliki mutation rate tinggi ditemukan pada isolat bakteri patogen. ${ }^{14,15}$ Beberapa contohnya yaitu, Escherichia coli, Salmonella typhimurium, Helicobacter pylori dan Pseudomonas aeruginosa, dan diketahui sebanyak $1 \%$ hingga $36 \%$ isolat klinik adalah mutator. ${ }^{16,17}$

Bakteri penghasil ESBL umumnya resisten terhadap antibiotik cephalosporin generasi ketiga, seperti cefotaxim, cefriaxon, dan ceftazidim. Serta mengalami resisten silang terhadap ciprofloxacin. Data terbaru RS. Dr. Soetomo Surabaya menyebutkan bahwa hanya beberapa antibiotik yang efektif terhadap bakteri penghasil ESBL. ${ }^{3}$

Pada penelitian ini akan ditentukan mutation rate bakteri $E$. coli penghasil ESBL yang diisolasi dari sampel urin pasien ISK di Rumah Sakit Dr. Soetomo Surabaya.

\section{Bahan dan Metode}

Penelitian ini bersifat observasional deskriptif dengan rancangan cross sectional. Lokasi penelitian berada di Instalasi / SMF Mikrobiologi Klinik Rumah Sakit Dr. Soetomo Surabaya. Sampel penelitian berupa bakteri E. coli penghasil ESBL sebanyak 24 sampel yang berasal dari spesimen urin pasien rawat 
inap Rumah Sakit Dr. Soetomo periode Januari hingga Maret tahun 2013. Penelitian ini telah mendapat pernyataan laik etik dari Komite Etik Penelitian Kesehatan RSUD. Dr. Soetomo dengan nomor surat 93/Panke.KKE/IV/2013.

Isolat Bakteri E. Coli

Isolat bakteri $E$. coli didapat dari spesimen urin yang dikirim ke Instalasi Mikrobiologi Klinik Rumah Sakit Dr. Soetomo Surabaya yang telah diuji kepekaan menggunakan metode Kirby-Bauer disk diffusion. Hasil kultur menunjukkan bahwa bakteri tersebut menghasilkan ESBL sesuai dengan Clinical and Laboratory Standards Institute (CLSI) 2012.

Penentuan Mutation Rate Menggunakan Metode Luria Delbrük

Mutation rate pada bakteri $E$. coli ditentukan melalui beberapa tahap. Pertama, dilakukan peremajaan isolat $E$. coli yang sebelumnya disimpan pada suhu $-80^{\circ} \mathrm{C}$ pada media blood agar. Bakteri diinkubasi semalam pada suhu $37{ }^{\circ} \mathrm{C}$. Keesokan harinya dilakukan subkultur dari koloni yang tumbuh pada media cair nutrient broth sebanyak McFarland 0,5 dan diinkubasi pada suhu $37^{\circ} \mathrm{C}$ selama 18-20 jam. Selanjutnya dilakukan dilusi terhadap hasil kultur pada media cair nutrient broth sampai tercapai kepadatan bakteri $2 \times 10^{4}$ CFU per ml. Kemudian diambil sebanyak $50 \mu \mathrm{l}$ dari suspensi bakteri tersebut untuk dimasukkan ke dalam tabung yang berisi $2 \mathrm{ml}$ media nutrient broth sebanyak 40 tabung. Lalu, sebanyak $1,5 \mathrm{ml}$ suspensi bakteri diambil dan disentrifus pada kecepatan $13.000 \mathrm{rpm}$ selama 15 menit. Lalu pada pelet ditambahkan $200 \mu \mathrm{l} \mathrm{NaCl}$ 0,85\%. Pelet kemudian diinokulasikan pada media agar darah yang telah diberi rifampicin $100 \mu \mathrm{g} / \mathrm{ml}$ pada masing-masing plate, kemudian diinkubasi pada suhu $37{ }^{\circ} \mathrm{C}$. Keesokan harinya diamati ada tidaknya pertumbuhan bakteri. Kemudian dihitung koloni yang tumbuh. Perhitungan nilai mutation rate menggunakan rumus Luria Delbrük:

$$
\mu=-(1 / N) \ln P_{0}
$$

Keterangan:

$\mu=$ Mutation rate

$\mathrm{N}=$ Jumlah sel bakteri yang tumbuh pada media kultur.

$\mathrm{Po}=$ proporsi kultur tanpa bakteri mutan

Uji Kepekaan Difusi Cakram Terhadap Meropenem dengan Metode Kirby Bauer

Uji kepekaan difusi cakram terhadap meropenem dilakukan dengan cara metode Kirby Bauer. Cakram yang berisi antibiotik diletakkan pada media agar yang telah ditanam bakteri yang akan berdifusi pada media agar tersebut. Area jernih menunjukkan adanya hambatan pertumbuhan bakteri oleh agen antibiotik pada permukaan media agar. ${ }^{18}$ Zona hambat $>23 \mathrm{~mm}$ dinilai sebagai susceptible, zona hambat $22 \mathrm{~mm}$ dinilai sebagai intermediate, dan zona hambat $<19 \mathrm{~mm}$ dinilai sebagai resistant

\section{Jumlah Pengulangan Kultur}

Hal yang juga penting untuk diperhatikan adalah jumlah kultur untuk masing-masing sampel yang dilakukan secara bersamaan atau paralel. Semakin banyak jumlah kultur yang dilakukan maka nilai ketepatan juga akan meningkat. Pada umumnya jumlah pengulangan yang diperlukan sebanyak 20 kultur.

\section{Ukuran Inokulum}

Parameter yang juga penting yaitu ukuran inokulum $\left(\mathrm{N}_{0}\right)$. Pada inokulum yang digunakan seharusnya tidak terdapat bakteri mutan dan harus dalam jumlah kecil. Pada percobaan yang dilakukan oleh Luria dan Delbruck, bakteri yang digunakan adalah 50 sampai 500 bakteri. Semakin kecil jumlah 
inokulum bakteri, maka semakin lama waktu yang diperlukan.

\section{Penghitungan Jumlah Bakteri}

Jumlah koloni bakteri yang tumbuh pada media agar dihitung dengan cara berikut. Bakteri disiapkan pada $2 \mathrm{ml}$ media cair. Kemudian diambil dan dimasukkan ke dalam satu tabung. Diambil sebanyak $1 \mathrm{ml}$,untuk disimpan pada suhu $-80{ }^{\circ} \mathrm{C}$. Dari suspensi bakteri tersebut diambil sebanyak $10 \mu$ dan ditambahkan $990 \mu \mathrm{NaCl}\left(10^{2}\right)$ sehingga didapatkan pengenceran 100x. Pengenceran selanjutnya yaitu mengambil $10 \mu \mathrm{l}$ suspensi bakteri dari pengenceran pertama $\left(10^{2}\right)$ dan ditambahkan $990 \mu \mathrm{l} \mathrm{NaCl}\left(10^{4}\right)$. Lalu mengambil $100 \mu \mathrm{l}$ suspensi bakteri pengenceran $10^{4}$ dan ditambahkan $900 \mu \mathrm{l}$ $\mathrm{NaCl} .\left(10^{5}\right)$. Lalu diambil $100 \mu \mathrm{l}$ suspensi bakteri pengenceran $10^{4}$ dan ditambahkan $900 \mu \mathrm{l} \mathrm{NaCl}\left(1^{6}\right)$. Diambil $100 \mu \mathrm{l}$ suspensi bakteri pengenceran $10^{4}$ dan ditambahkan $900 \mu \mathrm{l} \mathrm{NaCl}$.(107). Kemudian diambil $100 \mu \mathrm{l}$ suspensi bakteri dari dari tiap-tiap pengenceran $10^{4}-10^{7}$ dan diinokulasikan pada MHA, media diinkubasi pada suhu 37 ${ }^{\circ} \mathrm{C}$. Perrhitungan koloni ( $\left.\mathrm{Cfu} / \mathrm{ml}\right)$ menggunakan colony count/plate $\times 10 \times \mathrm{p}$. Jumlah sel dalam plate $=1,5 \times \mathrm{Cfu} / \mathrm{ml}$.
Pengolahan data

Data yang diperoleh dianalisis secara statistik menggunakan SPSS 20.0, diolah secara deskriptif dan disajikan dalam bentuk tabel.

Hasil

Pada penelitian ini bakteri E. coli penghasil ESBL ditumbuhkan pada media Mueller Hinton yang mengandung rifampisin dan tanpa rifampicin. Kultur bakteri pada media yang mengadung rifampicin didapatkan: 1. plate yang tidak ada pertumbuhan bakteri, 2. Ada plate dengan sebagian bakteri yang tumbuh dan tidak tumbuh dan, 3. Ada pertumbuhan bakteri pada seluruh plate. Lalu ditentukan nilai mutation rate dari bakteri tersebut. Nilai mutation rate $E$. coli penghasil ESBL dari spesimen urin pasien rawat inap Rumah Sakit Dr. Soetomo Surabaya ditampilkan pada Tabel 1.

Dari keseluruhan sampel pada penelitian ini didapatkan bakteri $E$. coli penghasil ESBL masuk dalam kategori strongly hypermutable pada 12 sampel dengan nilai frekuensi mutasi $\geq 4 \times 10^{-7}$ (Tabel 3). Sementara sisanya sebanyak 12 sampel E. coli penghasil ESBL masuk dalam kategori weakly hypermutable dengan nilai frekuensi mutasi $4 \times 10^{-8} \leq f<4 \times 10^{-7}$ yang ditunjukkan pada Tabel 4. 
Tabel 1. Nilai mutation rate E. coli penghasil ESBL.

\begin{tabular}{ccccc}
\hline No & ID Sampel & Plate Tanpa Koloni Mutasi & $\mathrm{N}: 1.5 \times \mathrm{cfu} / \mathrm{ml}$ & Nilai Mutation Rate \\
\hline 1 & 24088 & 0 & 251,250 & $210 \times 10^{-7}$ \\
\hline 2 & 44806 & 0 & 262,500 & $210 \times 10^{-7}$ \\
\hline 3 & 24276 & 0 & $28,593,750$ & $1.8 \times 10^{-7}$ \\
\hline 4 & 24508 & 0 & 420,000 & $126 \times 10^{-7}$ \\
\hline 5 & 4379 & 20 & 270,000 & $3,9 \times 10^{-7}$ \\
\hline 6 & 6436 & 20 & 360,000 & $1,4 \times 10^{-7}$ \\
\hline 7 & 4187 & 20 & 326,250 & $1,5 \times 10^{-7}$ \\
\hline 8 & 4539 & 20 & $12,843,750$ & $3,9 \times 10^{-7}$ \\
\hline 9 & 24547 & 20 & $10,312,500$ & $4,9 \times 10^{-7}$ \\
\hline 10 & 24254 & 19 & 408,000 & $1,2 \times 10^{-7}$ \\
\hline 11 & 4278 & 10 & 420,000 & $16 \times 10^{-7}$ \\
\hline 12 & 23727 & 18 & 210,000 & $4,7 \times 10^{-7}$ \\
\hline 13 & 24313 & 2 & 191,250 & $120 \times 10^{-7}$ \\
\hline 14 & 4380 & 12 & 363,750 & $14 \times 10^{-7}$ \\
\hline 15 & 4913 & 1 & 487,500 & $61 \times 10^{-7}$ \\
\hline 16 & 4866 & 18 & 195,000 & $5,1 \times 10^{-7}$ \\
\hline 17 & 4274 & 3 & 262,000 & $72 \times 10^{-7}$ \\
\hline 18 & 24289 & 18 & 378,750 & $2,6 \times 10^{-7}$ \\
\hline 19 & 4185 & 19 & 251,250 & $1,9 \times 10^{-7}$ \\
\hline 20 & 4297 & 12 & 168,000 & $30 \times 10^{-7}$ \\
\hline 21 & 4470 & 18 & $4,968,750$ & $2,1 \times 10^{-7}$ \\
\hline 22 & 4305 & 5 & $5,718,750$ & $1,9 \times 10^{-7}$ \\
\hline 23 & 25046 & 10 & $33,281,250$ & $2,0 \times 10^{-7}$ \\
\hline 24 & 24656 & 4 & $13,406,250$ & $1,2 \times 10^{-7}$ \\
\hline & & &
\end{tabular}

Tabel 2. Kategori mutation rate pada E. coli. ${ }^{19}$

Tipe Mutator Frekuensi Mutasi

Hypomutable

$f \leq 8 \times 10^{-9}$

Normomutable

$8 \times 10^{-9}<f<4 \times 10^{-8}$

Weakly hypermutable

$4 \times 10^{-8} \leq f<4 \times 10^{-7}$

Strongly hypermutable

$f \geq 4 \times 10^{-7}$

Tabel 3. E. coli penghasil ESBL kategori strongly hypermutable.

\begin{tabular}{ccc}
\hline No & ID sampel & Nilai Mutation rate \\
\hline 1 & 4278 & $16 \times 10^{-7}$ \\
\hline 2 & 23727 & $4,7 \times 10^{-7}$ \\
\hline 3 & 24313 & $120 \times 10^{-7}$ \\
\hline 4 & 4380 & $14 \times 10^{-7}$ \\
\hline 5 & 24088 & $210 \times 10^{-7}$ \\
\hline 6 & 4913 & $61 \times 10^{-7}$ \\
\hline 7 & 4866 & $5,1 \times 10^{-7}$ \\
\hline 8 & 4274 & $72 \times 10^{-7}$ \\
\hline 9 & 44806 & $201 \times 10^{-7}$ \\
\hline 10 & 4297 & $30 \times 10^{-7}$ \\
\hline 11 & 24547 & $4,9 \times 10^{-7}$ \\
\hline 12 & 24508 & $126 \times 10^{-7}$ \\
\hline
\end{tabular}


Tabel 4. E. coli penghasil ESBL kategori weakly hypermutable.

\begin{tabular}{ccc}
\hline No & ID sampel & Nilai Mutation rate \\
\hline 1 & 4278 & $1,2 \times 10^{-7}$ \\
\hline 2 & 23727 & $3,9 \times 10^{-7}$ \\
\hline 3 & 24313 & $2,6 \times 10^{-7}$ \\
\hline 4 & 4380 & $1,9 \times 10^{-7}$ \\
\hline 5 & 24088 & $1,4 \times 10^{-7}$ \\
\hline 6 & 4913 & $1,5 \times 10^{-7}$ \\
\hline 7 & 4866 & $2,1 \times 10^{-7}$ \\
\hline 8 & 4274 & $3,9 \times 10^{-7}$ \\
\hline 9 & 44806 & $1,9 \times 10^{-7}$ \\
\hline 10 & 24289 & $1,8 \times 10^{-7}$ \\
\hline 11 & 24547 & $2,0 \times 10^{-7}$ \\
\hline 12 & 24508 & $1,2 \times 10^{-7}$ \\
\hline
\end{tabular}

\section{PEMBAHASAN}

Adanya permasalahan kondisi resistensi di dunia medis dan lingkungan menyebabkan peningkatan patogen penghasil ESBL. Di Amerika Selatan, diketahui prevalensi Klebsiella pneumonia penghasil ESBL mencapai $55 \%$ dan E. coli sebesar $10 \% .{ }^{20}$ Sementara di Asia Tenggara (Malaysia, Filipina, Singapura, Thailand, dan Vietnam) E. coli penghasil ESBL isolat ISK paling tinggi ditemukan di Vietnam. Sejak 2010-2011 diketahui ada peningkatan secara umum di kawasan tersebut, dan pada tahun 2011-2013 diketahui sekitar 40\%. ${ }^{21}$

Insiden peningkatan ESBL ini dipengaruhi oleh beberapa faktor antara lain durasi tinggal di Rumah Sakit, durasi perawatan di ICU, penyakit primer yang parah, intubasi, katerisasi pada saluran kemih atau vaskuler, serta penggunaan antibiotik berulang khususnya cephalosporin generasi ketiga dan keempat. ESBL juga menjadi masalah pada pasien rawat jalan yang sering mendapatkan resep quinolone dan cephalosporin generasi ketiga. ${ }^{5}$

Pada penelitian ini mutation rate ditentukan menggunakan metode LuriaDelbrück, diketahui distribusi mutation rate resisten rifampicin pada $E$. coli penghasil ESBL yang diisolasi dari urin pasien penderita ISK adalah $50 \%$ bertipe strongly hypermutable $\left(f \geq 4 \times 10^{-7}\right)$ (Tabel 3$)$ dan $50 \%$ sisanya adalah weakly hypermutable $(4 \times 10$ ${ }^{8} \leq f<4 \times 10^{-7}$ ) (Tabel 4). Penemuan ini menunjukkan bahwa mutation rate pada $E$. coli penghasil ESBL telah mengalami peningkatan. Sejalan dengan penelitian sebelumnya yang mendapatkan sebanyak $56 \%$ isolat penghasil ESBL yang berasal dari infeksi saluran kemih. ${ }^{1}$ Strain bakteri $E$. coli uropatogenik menunjukkan mutation rate yang tinggi jika dibandingkan dengan bakteri komensal lainnya. ${ }^{19,22,23}$ Bukti lain menunjukkan $E$. coli penghasil ESBL yang diisolasi dari urin telah mengalami peningkatan mutation rate sebanyak $40 \%$, sedangkan isolat mutator $\mathrm{ESBL}$ negatif hanya sebesar $26 \%{ }^{1}$

Penelitian ini menunjukkan bahwa telah terjadi mutasi pada bakteri $E$. coli penghasil ESBL yang diisolasi dari urin. Mutasi ini terjadi secara bertahap pada gen ancestor yang mengkode ESBL (seperti TEM-1, atau SHV-1, serta ancestor TEM-4 dan SHV-12) pada strain hypermutable yang membawa plasmid tersebut kemudian diikuti transfer plasmid ke strain nonhypermutable. Transfer plasmid secara horizontal antar strain rumah 
sakit semakin meningkatkan hypermutator penghasil ESBL. Hal ini karena strain hypermutable lebih resisten terhadap antibiotik. ${ }^{24}$ Penelitian lain juga menunjukkan adanya kecenderungan peningkatan mutation rate dengan resistensi terhadap antibiotik, yaitu sebanyak 3 kali pada $E$. coli $(p=0,0001), 1,8$ kali pada enterococci $(p=$ $0,016)$, dan 1,5 kali pada CoNS $(p=0,012)$. Hal ini menunjukkan bahwa penggunaan antibiotik dan seleksi yang terkait dengan resistensi antibiotik menyebabkan mutator semakin banyak. Selain faktor tersebut disebutkan bahwa respons imun inang dan kerusakan jaringan karena patogenesis juga meningkatkan jumlah mutator. ${ }^{25,}$, 26,27

Fenomena ini menunjukkan bahwa isolat $E$. coli penghasil ESBL di Rumah Sakit Dr. Soetomo Surabaya telah meningkatkan kemampuan adaptasinya terhadap paparan antibiotik jenis baru atau untuk mendapatkan fitur-fitur baru dalam kaitannya dengan kemampuan virulensi dan epidemik. ${ }^{28}$

\section{Kesimpulan}

Pada penelitian ini diketahui mutation rate resisten rifampicin pada $E$. coli penghasil ESBL isolat urin pasien penderita ISK di Rumah Sakit Dr. Soetomo Surabaya adalah $50 \%$ bertipe strongly hypermutable dan $50 \%$ adalah weakly hypermutable.

\section{Daftar Pustaka}

1. Baquero MR, Galan.JC, Turrientes MDC, Canton R, Coque TM, Martinez JS, Baquero F. Increaed Mutation Frequencies in Esherichia Coli Isolates Harboring Extended-Spectrum BLactamases. Antimicrobial Agent and Chemotherapy. 2005; 49(11):4754-4756.

2. Andersson $\mathrm{DI}$ and Levin BR. The Biological Cost of Antibiotic Resistance. Current Opinion in Microbiology. 1999. (2):289-493.
3. Kuntaman K, Lestari ES, Severin.JA, Kershof IM, Mertaniasih NM, Purwanta M, Hadi U, Johnson JR, Belkum A VV, Hendi A. Fluroquinolon - Resistant Escherichia coli Indonesia. Emerging Infectious Diseases. 2005; 11(9):1363-1369.

4. Paterson DL, Bonomo RA. ExtendedSpectrum beta-Lactamases: A Clinical Update. Clin Microbiol Rev. 2005; 18(4):657-686.

5. Reinthaler FF, Feierl G, Galler H, Haas D, Leitner E, Mascher F, Melkes A, Posch J, Winter I, Zarfel G, Marth E. ESBL Producing $E$. coli in Austrian Sewage Sludge. J Waters. 2009; 11:052.

6. Bush K, Jacoby Ga, Medeiros Aa. A Functional Classification Scheme For $\beta$ Lactamases and Its Correlation with Molecular Structure. Antimicrob Agents Chemother. 1995; 39:1211-1233.

7. Massova I, Mobashery S. Kinship and Diversification of Bacterial PenicillinBinding Proteins and $\beta$-Lactamases. Antimicrob Agents Chemother 1998; 42: 1-17.

8. Bonnet $\mathrm{R}$, Sampaio JI, Chanal $\mathrm{C}$ et al. A Novel Class A Extended-Spectrum $\beta$ Lactamase (Bes-1) in Serratia marcescens Isolated in Brazil. Antimicrob Agents Chemother. 2000; 44:3061-3068.

9. Sullivan A, Edlund C, and Nord CE. Effect of Antimicrobial Agents on The Ecological Balance of Human Microflora. Lancet Infectious Diseases. 2001; 1: 101-14.

10. Sjölund M, Wreiber K, Andersson DI et al. Long-Term Persistence of Resistant Enterococcus Species After Antibiotic Treatment to Eliminate Helicobacter pylori. Annals of Internal Medicine. 2003.

11. Martinez $\mathrm{JL}$ and Baquero $\mathrm{F}$. Mutation Frequencies and Antibiotic Resistance. Antimicrobial Agent and Chemotherapy. 2000; 4(4):1209-1214.

12. Tenailon $O$, Denamur $E$, and Matic I. Evolutionary Significance of Stress Induced Mutagenesis in Bacteria. 
Elsevier Treds In Microbiology. 2004; 12:264-270.

13. Luria S and M Delbru"ck. Mutations of Bacteria from Virus Sensitivity to Virus Resistance. Genetics. 1943; 28:491-511.

14. Matic I, Radman M, Taddei F et al. Highly Variable Mutation Rates in Commensal and Pathogenic Escherichia coli. Science. 1997; 277:1833-4.

15. Giraud A, Radman M, Matic I et al. The Rise and Fall of Mutator Bacteria. Current Opinion in Microbiology. 2001; 4: 582-5.

16. Leclerc JE, Li B, Payne WL et al. High Mutation Frequencies Among Escherichia coli and Salmonella Pathogens. Science. 1996; 274:1208-11.

17. Oliver A, Canton R, Campo $P$ et al. High Frequency of Hypermutable Pseudomonas Aeruginosa in Cystic Fibrosis Lung Infection. Science. 2000. 288:1251-4.

18. Pratiwi St. Mikrobiologi Farmasi. Yogyakarta: Penerbit Erlangga. 2008.

19. Baquero MR, Al Nilsson, MC Turrientes, D Sandvang, JC Gala'N, JL Martı'Nez, N Frimodt-Moller, $\mathrm{F}$ Baquero, and $\mathrm{DI}$ Andersson. Polymorphic Mutation Frequencies in Escherichia coli: Emergence of Weak Mutators in Clinical Isolates. J Bacteriol. 2004; 186:55385542.

20. Gales AC, Sader HS, Jones RN, Sentry Participants Group (Latin America). Urinary Tract Infection Trends in Latin American Hospitals: Report from The Sentry Antimicrobial Surveillance Program (1997-2000). Diagn Microbiol Infect Dis. 2002; 44(3):289-299.

21. Lob S, M Hackel, D Biedenbach, D Sahm, R. Badal, Trends in ESBL-Production and Susceptibility for E. coli from Urinary Tract Infections In Southeast Asia: Smart 20102013. USA: A Johnson, D Hoban
International Health Management Associates, Inc.

22. Denamur ES, Bonacorsi A, Giraud $P$, Duriez $F$, Hilali $C$, Amorin $E$, Bingen $A$, Andremont B, Picard F, Taddei and I Matic. High Frequency of Mutator Strains Among Human Uropathogenic Escherichia coli Isolates. J Bacteriol. 2002; 184:605-609.

23. Miller K, AJ O'neill, and I Chopra. Escherichia coli Mutator Present an Enhanced Risk for Emergence of Antibiotic Resistance During Urinary Tract Infections. Antimicrob Agents Chemother. 2004; 48:23-29.

24. Oliver A, R Canto'N, P Campo, F Baquero, and $\mathrm{J}$ Bla'Zquez. High Frequency of Hypermutable Pseudomonas aeruginosa in Cystic Fibrosis Lung Infection. Science. 2000; 288:1251-1254.

25. Gustafsson I, Sjölund M, Torell E, Johannesson M, Engstrand L, Cars O, and Dan IA. Bacteria with Increased Mutation Frequency and Antibiotic Resistance are Enriched in The Commensal Flora of Patients with High Antibiotic Usage. Journal of Antimicrobial Chemotherapy. 2003; 52:645-650. doi: 10.1093/Jac/Dkg427

26. Mao EF, Lane L, Lee J. et al. Proliferation of Mutators in A Cell Population. Journal of Bacteriology. 1997; 179:417-22.

27. Giraud A, Matic I, Radman M. et al. Mutator Bacteria as A Risk Factor in Treatment of Infectious Diseases. Antimicrobial Agents And Chemotherapy. 2002; 46:863-5.

28. Martı'Nez JL, and F Baquero. Interactions Among Strategies Associated with Bacterial Infection: Pathogenicity, Epidemicity, and Antibiotic Resistance. Clin Microbiol Rev. 2002; 15:647-679. 